\title{
TOTAL NONDIALYZABLE SOLIDS (TNDS) IN HUMAN URINE. XIII. IMMUNOLOGICAL DETECTION OF A COMPONENT PECULIAR TO RENAL CALCULOUS MATRIX AND TO URINE OF CALCULOUS PATIENTS *
}

\author{
By WILliam H. BOYCE, J. STANTON KING, JR. $\dagger$ ANd MARVEL L. FIELDEN \\ (From the Departments of Urology and Biochemistry, The Bowman Gray School of Medicine \\ of Wake Forest College, Winston-Salem, N. C.)
}

(Submitted for publication December 1, 1961 ; accepted January 25, 1962)

An organic matrix is universally present in mammalian bone, teeth, salivary, biliary, and urinary calculi. Such matrices invariably contain both protein and carbohydrate and appear by gross analyses to be mucosubstances.

The interrelations of organic matrix and crystals of urinary calculi suggest that stone building is a process of crystal growth upon the molecular surfaces and within the interstices of a "preformed" mucoid matrix $(1,2)$. "Preformed" here is used in terms of addition of as little as a single molecule or as much as the total matrix mass.

Analyses of total urinary stone matrix suggested that it was not derived from bone matrix but could represent an altered form of the urinary uromucoid which is contained in the $\mathrm{R}-1$ fraction of normal urine $(3,4)$. The matrix contained less glucide than normal uromucoid and no sialic acid. Dulce (5), Thiele (6), and Gasser, Brauner and Preisinger (7) have independently concluded from their analyses that mucoproteins of the matrix of calcium stones differ from total colloids in normal urine; hence some process of selectivity is involved. Whether these differences existed prior to stone formation has not been determined. The relative insolubility of stone matrix has hampered study of this material. Anderson, Lepper and Winzler (8) produced antibodies in rabbits against some components of the insoluble organic matrix of calcigerous renal calculi. These antibodies gave immunological reactions with components of both $\alpha$ - and $\beta$-globulin fractions of normal and

* Supported by Public Health Service Grant A-259, National Institutes of Health, and by grants from the John A. Hartford Foundation, the Mary Reynolds Babcock Foundation, and the American Urological Research Foundation.

† Helen Hay Whitney Foundation Research Fellow. poliomyelitis urinary colloids. A specific increase of the immunological reactivity to these antibodies was noted in the urine of poliomyelitis patients, and a positive correlation was established with daily urine volume and calcium-binding ability of the urinary colloids.

Is stone matrix some essential, actively mineralsequestering molecule occurring only in the urine of patients who form calculi, or is it only a nonessential adsorbate formed of the various proteins and mucosubstances which occur in normal urine? Stated conversely, if ambient conditions for crystallization are met, can calculi form and grow in otherwise normal urine or do there exist individuals who have no "matrix molecule" and hence may have crystalluria but are incapable of concrement formation? The present studies were undertaken to test the hypothesis that, although normal mucosubstances of urine may be incorporated by adsorption into the matrix, there must be peculiar or aberrant molecules to account for the genesis of renal calculi.

\section{METHODS}

Preparations of antigens. Individual renal calculi removed at surgery were immediately scrubbed with a sterile brush to remove surface debris. A saw cut was made through the center of the calculus and the dust was analyzed for crystalline composition. The halves were placed in Visking cellophane casing and agitated in a vacuum-driven apparatus containing 5 per cent (wt/vol) disodium EDTA adjusted to $\mathrm{pH} 7.8$ with sodium hydroxide. Decrystallization was grossly complete in 72 to 96 hours. The cellophane casings were mechanically dialyzed against distilled water and the nondialyzable matrix recovered by lyophilization. This dry powder was stored and resuspended in distilled water as needed for immunological studies. A solution of $3 \mathrm{mg}$ matrix per $\mathrm{ml}$ was most commonly used as a "high" concentration of matrix for precipitin reaction with an equal volume of unfractionated rabbit antimațix serum. Ap- 
proximately 25 per cent of such lyophilized matrix is readily soluble in this volume of water but suspensions of whole matrix were used in the various studies, since a sufficient quantity of the relatively insoluble material was demonstrated to diffuse through a 1 per cent agar gel. The opacity of such suspensions and the uncertainty of using supernates hampered the determination of optimal proportions of antigen and antibody by the classical tube dilution techniques. The 6-well Ouchterlony agar plate was utilized to determine optimal proportions by placing serial dilutions of the matrix suspension in the peripheral wells. Matrix concentrations of 0.5 to $1.0 \mathrm{mg}$ in $0.3 \mathrm{ml}$ distilled water gave optimal concentrations for precipitin reactions with $0.3 \mathrm{ml}$ of unfractionated rabbit immune serum in practically every experiment.

Thirty-seven calcigerous calculi, weighing 1 to $14 \mathrm{~g}$, were studied individually. Eight were "staghorn" calculi containing magnesium ammonium phosphate; 7 were relatively pure calcium phosphate calculi; 10 were mixed phosphate and oxalate calculi; and 12 were principally calcium oxalate. Calcium oxalate and phosphate calculi weighing less than $1 \mathrm{~g}$ were pooled according to the major crystalline component, and processed as representative groups. Much matrix material was available as lyophilized powder from previous studies, and pools of matrix stored for 3 to 5 years were found to give immunological reactions equivalent to freshly prepared matrix. No significant differences in immunological reactivity were detected when freshly prepared unlyophilized matrix was compared with lyophilized samples from the same calculus. For convenience, the lyophilized powder was adopted for routine use.

Matrix from pure uric acid or cystine calculi (3) was so insoluble and nondiffusible in agar gel as to preclude study by these methods.

Preparation of other test substances from urine and serum followed the previously described techniques (9). "TNDS" refers to total nondialyzable solids of urine recovered by lyophilization of 24-hour urine specimens after dialysis against water in Visking cellophane. "R-1" fraction is that portion of TNDS not ultrafiltrable through collodion membranes of $20 \mathrm{~m} \mu$ average pore diameter and insoluble in $0.1 \mathrm{M}$ veronal buffer of $\mathrm{pH}$ 8.6. "RS-1" fraction of TNDS is not ultrafiltrable through these collodion membranes but is soluble in veronal buffer. "UF-O" is the portion of TNDS which is filtrable through collodion membranes of $20 \mathrm{~m} \mu$ average pore diameter.

Preparation of substances of bacterial origin. Thioglycolate broth cultures of Aerobacter aerogenes, Proteus mirabilis and rettgeri, Pseudomonas aeruginosa, Paracolon, Escherichia coli, alpha-enterococci, and Staphylococcus hemolyticus from the urines of patients with urinary calculi were incubated for 2 weeks, and either the whole broth or vacuum-dehydrated solids were utilized as antigens. These same cultures were repeated after adding total and fractionated lyophilized nondialyzable urinary solids ( $3 \mathrm{mg}$ per $\mathrm{ml}$ ) from normal urine to the broth before inoculation. As a further test, $60 \mathrm{ml}$ of fresh normal urine to which $60 \mathrm{mg}$ of normal fraction R-1 had been added was inoculated with $P$. mirabilis and incubated at $37^{\circ} \mathrm{C}$ for 2 days. After removing the organisms by centrifugation, the supernates from these various cultures were tested for immunological reactivity to matrix immune serum.

Five patients with large calculi were studied by a special technique. Prior to surgery, one to three 24-hour urine specimens were processed to obtain samples of the TNDS and the RS-1 and R-1 fractions. The organisms recovered from the urine were preserved in thioglycolate broth. At surgery, all calculous material from each patient was processed for recovery of the total matrix. Three test substances were thus available from each patient: the bacteria, the urinary mucosubstances, and the stone matrix.

Preparation of immune serum. The rabbit matrix immune serum was prepared by foot-pad injections of suspensions of lyophilized matrix or other antigen in complete Freund's adjuvant (10). Sera from adult rabbits, which had been injected with the same antigen, were pooled. In addition to immune serum prepared with pooled matrix, one to four "batches" of immune serum were prepared for matrix from ten individual calculi. The predominant crystalline composition of these included three magnesium ammonium phosphate calculi, three apatite phosphate calculi, three oxalate calculi, and one mixed apatite and oxalate monohydrate calculus.

Unfractionated immune rabbit serum was used in all experiments reported here.

Test procedures for immunological reactivity. Previously described methods (10), utilizing the Ouchterlony agar gel plates, were followed. The plates with 6 peripheral circular wells of $0.3 \mathrm{ml}$ capacity and $10 \mathrm{~mm}$ distance from the center well were suitable for this study, in which comparison of precipitin reactions of a large number of unknowns was desirable. A control well in each plate insured that the observed results were due to immunological reactions rather than to changes in concentration or other mechanical artifacts. Particular attention was paid to negative reactions; i.e., failure of a precipitin zone to appear in agar gel diffusions of matrix with any of the various immune sera, or persistence of a precipitin zone after the immune serum had been absorbed with a potential antigen. In these instances, the test substance was made up in approximately a saturated solution (usually 3 to $9 \mathrm{mg}$ per $\mathrm{ml}$ ). Beginning with the concentrated solution, serial dilutions were made to $1: 1,000$ of the original concentrate and these were tubed against the immune serum in an effort to cross the zone of optimum antibody concentration.

The data summarized in this report represent more than 1,800 determinations in which a potentially antigenic test substance was diffused against an immune serum. The observations include repeated preparations of antigens and immune sera over a period of 2 years. The data reported here have thus been repeatedly reproduced. 


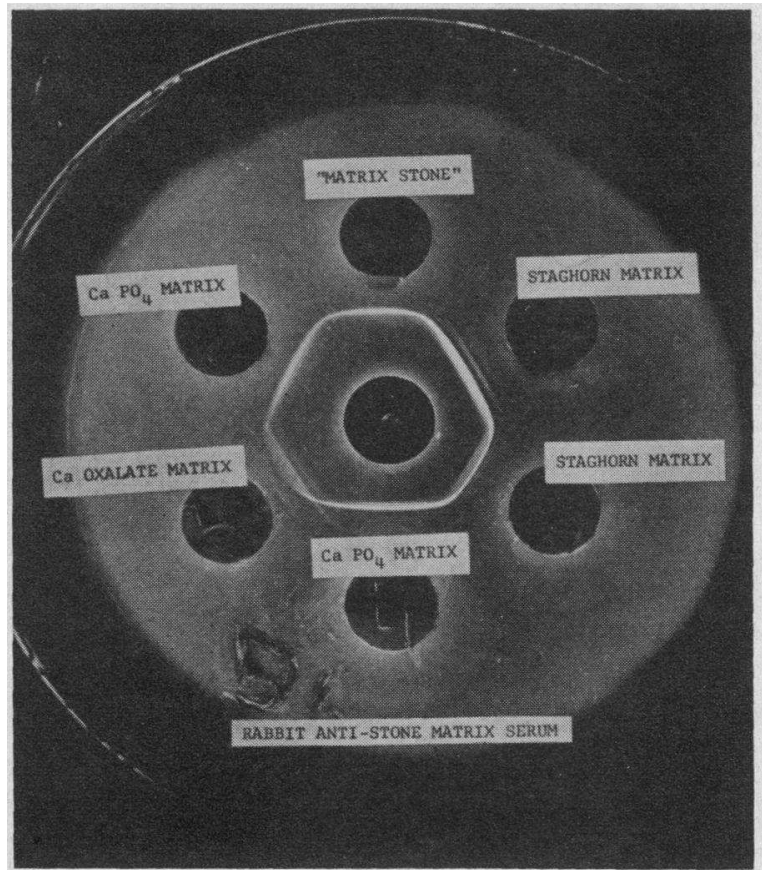

Fig. 1. Typical immunological Reactivity of maTRICES FROM CALCULI OF DIFFERENT CRYSTALLINE COMPOSITION TO RABBIT SERUM IMMUNE TO MATRIX FROM A SINGLE CAlCUlus. Center well contains serum immune to staghorn matrix from a calculus containing magnesium ammonium phosphate, tricalcium phosphate, and apatite crystals. Peripheral wells, numbered clockwise with well 1 at 12 o'clock position, contain whole matrix from calculi of indicated predominant crystalline composition. "Matrix stone" in well 1 contains roentgenolucent concretion with small amount of apatite and tricalcium phosphate crystals. Well 2 contains the antigen used in preparation of the antiserum. Well 5 contains matrix from a pool of calcium oxalate dihydrate calculi with "seed" spherules of apatite, all from patients without evidence of urinary infection. Note the dense precipitin zone of Substance A which gives a reaction of identity with all matrices. This zone remains alone and unaltered when the immune serum has been absorbed with human serum proteins and normal urinary nondialyzable solids.

\section{RESULTS}

Section I. Immunological reactivity of calculous matrix with matrix immune serum

Total nondialyzable matrix recovered from calcigerous urinary calculi is highly antigenic for rabbits. Precipitin reactions to all matrix preparations from individual and pooled calculi were obtained with each antiserum to pooled matrix and to each of the ten individual matrix immune sera.

In all of these experiments one zone of precipitation appeared first, persisted indefinitely in the gel, and was usually the most dense, indicating that it represented the largest quantity of antibodyantigen complex. The zone of precipitation, which appeared in all Ouchterlony plates containing matrix versus matrix immune sera, invariably gave a "reaction of identity" with other matrices. Designated "matrix substance A," it is demonstrated in Figure 1, and in the subsequent figures.

On the other hand, matrix immune sera gave no immunological reactivity with human erythrocyte membranes, human bone matrix, human saliva, or salivary stone matrix.

The Ouchterlony plates containing matrix immune sera revealed one to four distinct zones of precipitation with whole matrix in all preparations. This indicated that the antigens (and consequently the generated antibodies) were multiple. Matrices from 39 individual calculi were separately tested against three matrix immune sera prepared from matrices of calculi of different crystalline composition. In a single test of each preparation, four precipitin zones appeared in 1, three zones in 5 , two zones in 18 , and one zone in 13 . However, further testing of these same matrices in varying concentrations against other matrix immune sera revealed more than one antigenic substance in 38 of the specimens.

When the only seemingly "pure" matrix from among these 39 calculi was itself used as the antigen for preparation of matrix immune serum, the resulting antiserum gave two precipitin zones in Ouchterlony plates with the original antigen and with a number of matrices from other calculi. One zone was matrix substance A; the other was a component of normal urine. This matrix material gave an analysis of 17.5 per cent hexose, 5 per cent ash, 7.5 per cent nitrogen, 0.4 per cent hexosamine, a trace of hexuronic acid, and no sialic acid.

In general, the smooth, very dense apatite and calcium oxalate monohydrate calculi, from patients with minimal signs of urinary infection, contained matrix with only one or two zones of immunological reactivity with the various antisera. The more porous calculi, composed preponderantly of large crystals of magnesium ammonium phosphate and tricalcium phosphate, contained matrices with the greatest number of immunologically reactive substances. These crystalline types commonly occur in the presence of uri- 
nary infection and relatively high urinary $\mathrm{pH}$. The small ( 50 to $150 \mathrm{mg}$ ) calcium oxalate dihydrate calculi recovered from patients with sterile urine and relatively low urinary $\mathrm{pH}$ deserve special attention. These calculi have a prickly surface and invariably contain a smooth nuclear spherule of 1 to $2 \mathrm{~mm}$ in diameter, which is composed of apatite with a variable admixture of calcium oxalate monohydrate. This spherule is considered to represent the "true concretion"; the calcium oxalate dihydrate crystals are considered to represent surface crystallization of the type that occurs on a silk thread suspended in normal urine of low $\mathrm{pH}$. These calculi contained relatively less matrix substance $\mathrm{A}$ and relatively more zones of precipitation reactive to normal urinary protein immune sera (anti-TNDS serum) than any other calculi. This is illustrated in Figure 1, well 5. The relative increase in urinary proteins is attributed to a greater extent of entrapment of these substances within the interstices of the large calcium oxalate dihydrate crystals (11).

\section{Section II. Presence of blood serum proteins in calculous matrix}

Six of the ten individual matrix immune sera gave no zones of precipitation with whole serum from normal or stone-forming patients. With appropriate dilutions of serum proteins, 4 immune

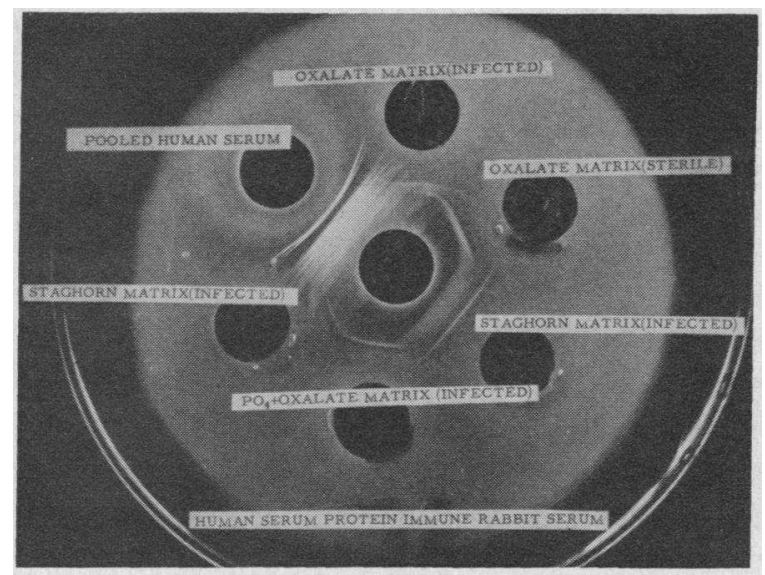

Fig. 2. PRESENCE OF hUMAN SERUM PROTEINS IN CERTAin RENAL CALCUli. Center well contains pooled rabbit sera immune to human serum proteins. Well 2 contains pooled matrix from small calcium oxalate dihydrate calculi from patients with sterile urine culture. Other wells contain matrix from calculi of varying composition, but all are from patients with urinary infection.

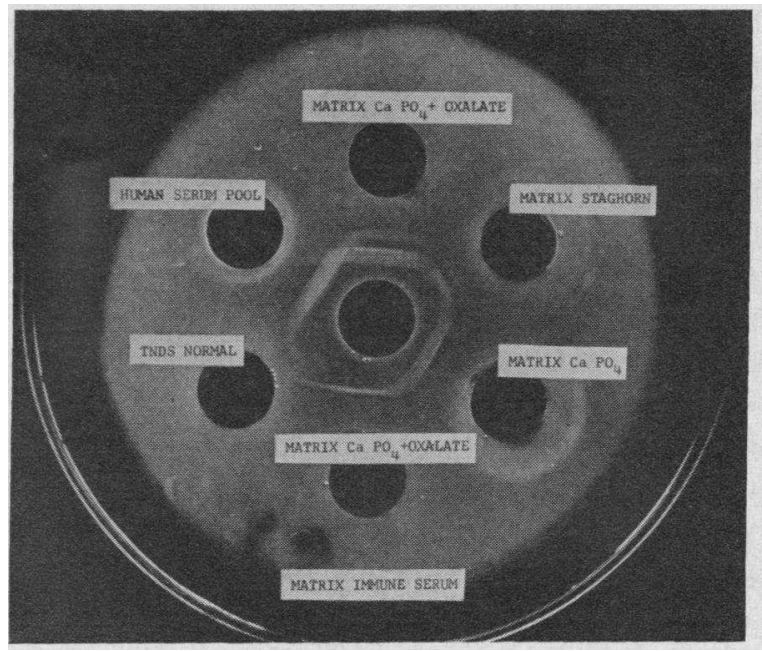

Fig. 3. PRESENCE OF ANTIBOdIES TO SERUM AND NORMAL URINARY PROTEINS IN MATRIX IMMUNE RABBIT SERA. Center well contains matrix immune serum prepared with antigen from staghorn calculus from a patient with $P$. mirabilis infection. Note the reaction of identity between serum and TNDS of normal urine and one of the zones of precipitation appearing in the matrix preparations. Note complete crossing of precipitin zones at wells 1 and 6 , indicating reaction of nonidentity between matrix substance $\mathrm{A}$ and serum or normal urinary solids.

sera gave one or two zones of precipitation. Twelve of 25 calculi recovered from patients known to have had bacterial urinary infections, including 7 of 8 staghorn calculi, contained one or two substances immunologically reactive with rabbit serum immune to human serum proteins (Figure 2). Absorption of the matrix immune serum with human serum prevented the appearance of one or two of the lesser zones of reactivity to stone matrix but did not alter the major reactive zone (substançe A) described in Section I above (Figures 3 and 4 ). In summary, the presence of one or more components with immunological reactivity to components of blood serum has been demonstrated in approximately one-half of calculi weighing more than $3 \mathrm{~g}$. Such components were common in patients known to have had urinary infections, but were not demonstrable in many calculi from patients who had no evidence of urinary infection.

\section{Section III. Presence of nondialyzable solids of normal urine in urinary calculi}

A. Uromucoid ( $R-1)$ fraction from normal urine. The R-1 fraction of urinary mucosubstances is 
highly antigenic and regularly produces rabbit immune serum of high titer (10). In the ten preparations of matrix immune sera, involving 36 rabbits, and in tests of samples of R-1 from 21 normal persons, purified by reprecipitation from distilled water with $0.58 \mathrm{M} \mathrm{NaCl}$, only two positive precipitin reactions between $\mathrm{R}-1$ and rabbit antimatrix serum were observed. In both instances, the precipitin zones in gel plates were barely detectable and occurred at concentrations of R-1 approximately one-tenth of that required for crude matrix. Absorption of matrix immune serum with as little as $1 \mathrm{mg} \mathrm{R}-1$ per $\mathrm{ml}$ of serum completely abolished the immunologic response to R-1 without affecting the substance " $\mathrm{A}$ " responses to whole matrix illustrated in Figure 1.

On the other hand, rabbit immune serum prepared with pure R-1 antigen gave a detectable immunological response to matrices from 17 of 26 individual calculi. It was necessary to increase the matrix concentration by three- to sixfold above that required for the demonstrations of

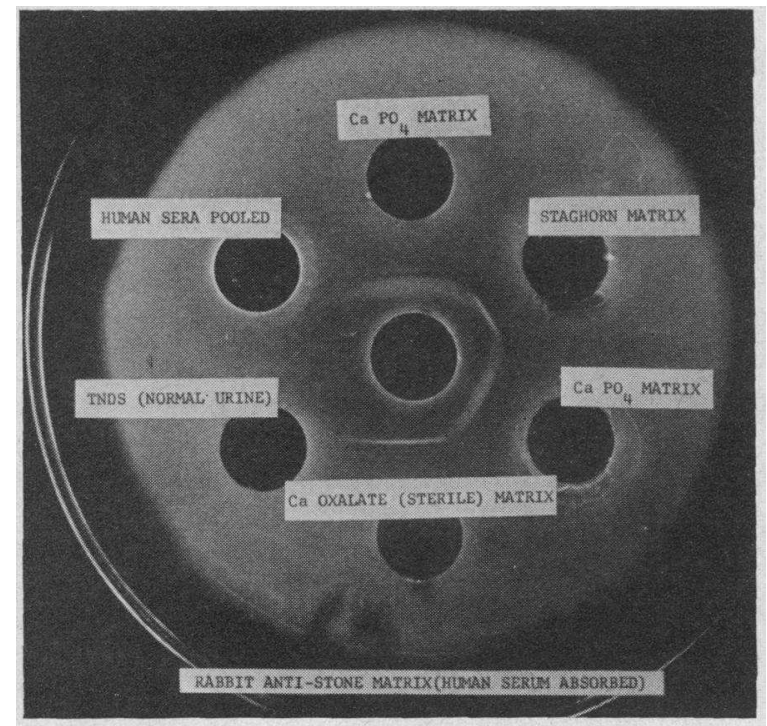

Fig. 4. Persistence of matrix substance A preCIPITIN REACTION AFTER REMOVAL OF ANTIBODIES TO HUMAN SERUM. Center well contains same matrix immune serum as that in Figure 3 after absorption with human serum and removal of the precipitate prior to diffusion. Concentrations of test substances in peripheral wells are the same as in Figure 3. This immune serum will give a precipitin reaction with $\mathrm{R}-1$ solids of normal urine but requires much greater relative concentrations of $R-1$ than exist in the TNDS in well 5 .

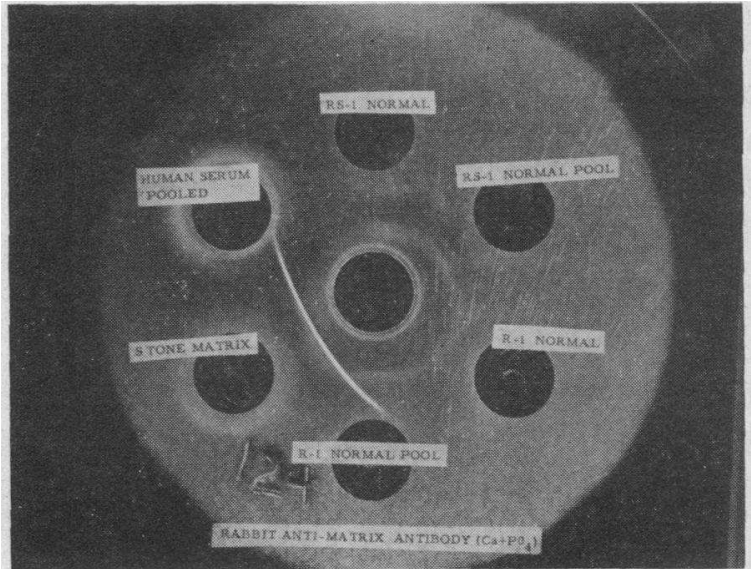

Fig. 5. Relative density of PRECipitin REACtions to MATRIX SUBSTANCE A AND NORMAL URINARY NONDIALYZABLE SOLIDS TO RABBIT SERUM IMMUNE TO APATITE CALCUlous Matrix. Each peripheral well contains 0.5 $\mathrm{mg}$ of indicated test substance.

precipitin reaction of matrix substance A with antimatrix as described in Section I.

In summary, these results are interpreted as indicative of the presence of R-1 in approximately two-thirds of large urinary calculi. However, it is usually present in barely detectable quantities, even by the extremely sensitive tests which in the above experiments will give unequivocal identification of 1 part R-1 in 100 parts of whole matrix.

$B$. Veronal-soluble, nonultrafiltrable (RS-1) components of normal urine. Eight of the ten antibody preparations of individual stone matrix gave one to three zones of immunological response to normal RS-1 solids. These precipitin lines in gel did not give reactions of identity with the matrix substance A response described in Section I (Figure 5). Furthermore, they were abolished by prior absorption of the matrix immune serum with total nondialyzable solids of normal urine, leaving the matrix reaction unaltered (Figure 6). Absorption of the matrix immune serum with human blood plasma usually removed all but one of the RS-1 reactive substances, which could then be removed by absorption with R-1 solids of normal urine.

$C$. The nondialyzable but ultrafiltrable solids of normal urine (fraction UF-O). This fraction gave no immunological reaction with any preparation of matrix immune serum. 
Section IV. Presence of nondialyzable components of the urine of calculous patients in urinary calculi.

$A$. The veronal-insoluble nonultrafiltrable $(R-1)$ fractions of urine from 26 patients with urinary calculi. These were tested against the ten preparations of matrix immune serum and 22 of the fractions gave immunological reactions of identity, with the matrix reaction described in Section I, with all of the matrix immune serum preparations. However, this reaction of identity with matrix substance A was removed from the calculous R-1 by repeated extractions with $0.58 \mathrm{M} \mathrm{NaCl}$. The residue gave good immunological response to normal R-1 immune serum after the immunological reaction of matrix substance $A$ to matrix immune serum was completely removed.

Matrix substance $\mathrm{A}$ is thus demonstrated to be

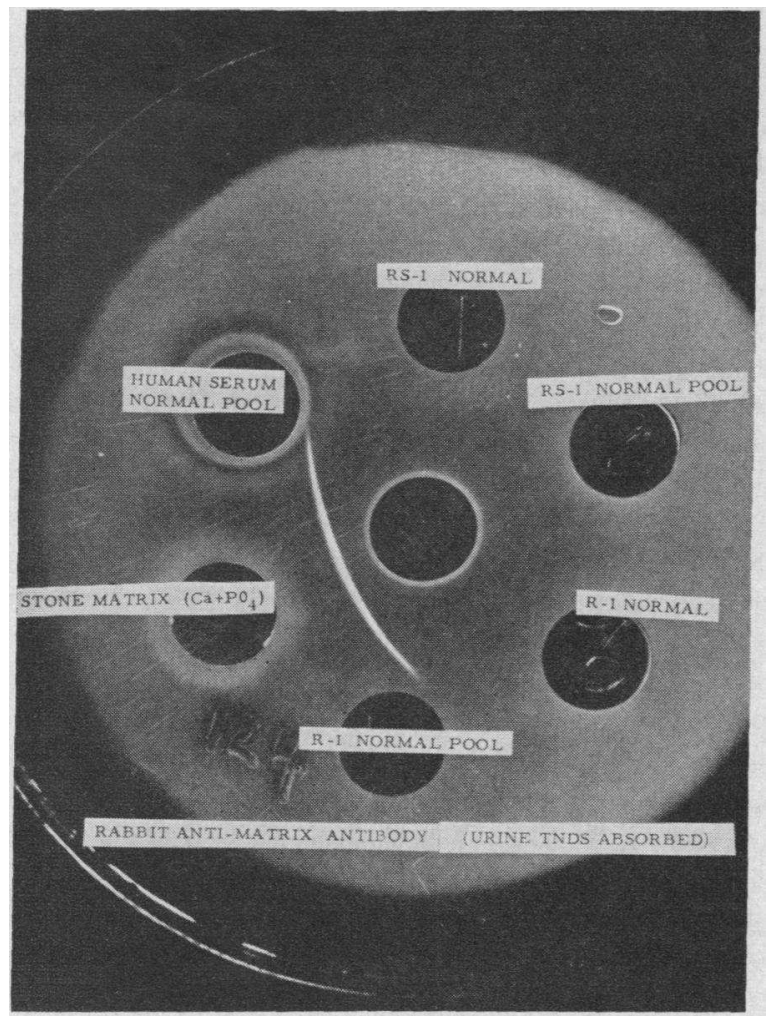

Fig. 6. Persistence of matrix substance A precipiTIN REACTION AFTER ABSORPTION OF MATRIX IMMUNE SERUM WITH TNDS OF NORMAL URINE. All components of the various wells are identical with those of Figure 5, with the exception of the apatite matrix immune serum in the center well, which has been absorbed with TNDS from normal urine.

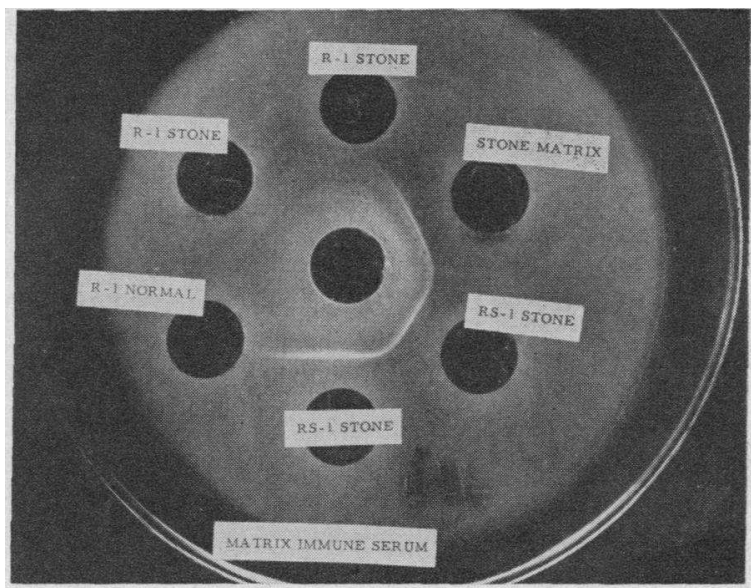

Fig. 7. IMMUNOLOGICAL REACTION OF IDENTITY BETWEEN RS-1 COMPONENTS OF URINE OF CALCULOUS PATIENTS AND MATRIX SUBSTANCE A FROM CALCULOUS MATRIX. Center well contains the same matrix immune serum as Figure 6 . Peripheral wells contain $0.5 \mathrm{mg}$ lyophilized dry weights of indicated test substances.

distinctly different immunologically from the R-1 fraction in normal and calculous urine, while the latter are immunologically identical. Matrix substance $A$ tends to remain as a contaminant of $R-1$ fraction of calculous urine unless it is thoroughly washed with $0.58 \mathrm{M} \mathrm{NaCl}$ or with veronal buffer.

$B$. The veronal-soluble nonultrafiltrable $R S-1$ components of calculous urine. Thirty patients with recent calculous growth and bilateral or very large calculi were studied. The RS-1 of every patient gave a distinct zone of precipitation with reaction of identity with calculous matrix substance $A$ and matrix immune serum (Figure 7). As judged by the density and length of the zones of precipitation, there was considerable variation in the quantity of substance A relative to the total RS-1 in these various urine specimens. In many preparations one or two additional zones of precipitin reaction were also observed in the gel diffusion plates (Figure 8). These were removed by absorption of the matrix immune serum with either TNDS of normal urine or with normal blood serum (Figure 9). Patients from the stone clinic, who were known to have had calculi in the past but who had not formed calculi in the preceding 12 months, were requested to submit 24 hour urine specimens to examination. The RS-1 solids from 2 patients gave a barely detectable reaction of identity with stone matrix substance A, and 23 failed to give such reaction. 


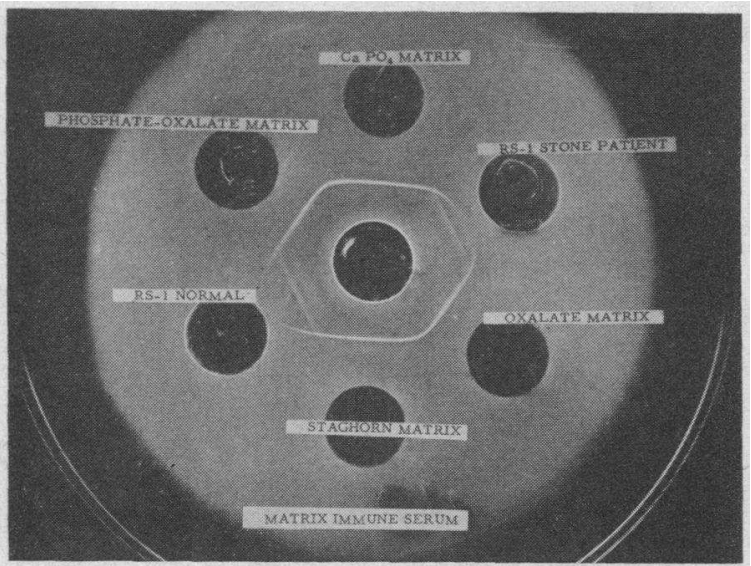

Fig. 8. IMMUNOLOGICAL REACtION OF NONIDENTITY BETWEEN RS-1 SOLIDS OF NORMAL URINE AND MATRIX SUBSTANCE A FROM CAlCUlous Matrix AND RS-1 SOLIDS OF URINE OF CALCUlous PATIENTS. All peripheral wells contain $0.5 \mathrm{mg}$ of indicated test substances.

When pooled RS-1 fraction from patients who were active stone-formers was placed on a DEAEcellulose column (in the hydroxide form) and eluted first with water and then with $0.05 \mathrm{M}$ $\mathrm{Na}_{2} \mathrm{HPO}_{4}$, material serologically identical with substance A came off in the second eluate, but none in subsequent eluates with a salt gradient. The reactive portion of the eluate was precipitable between 40 and 60 per cent saturation with ammonium sulfate.

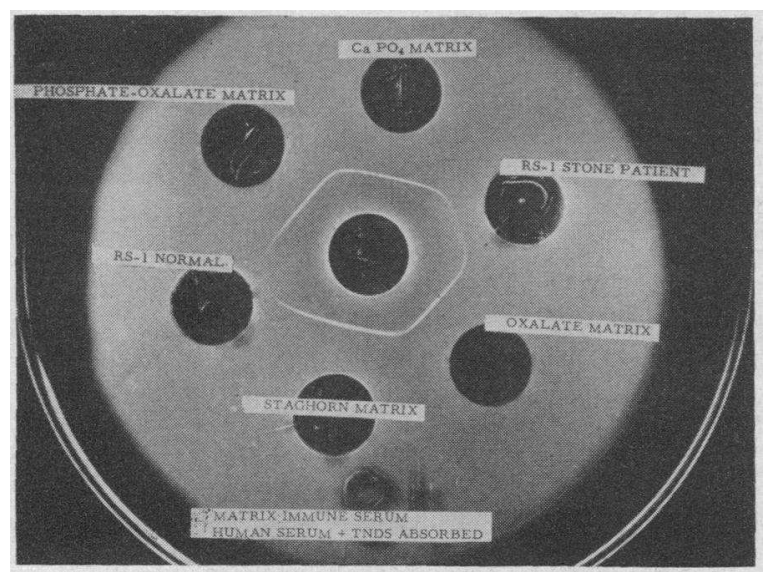

Fig. 9. Persistence of IMMUNOLOgical REACtion of IDENTITY BETWEEN MATRIX SUBSTANCE A FROM CALCULOUS MATRIX AND RS-1 SOLIDS FROM URINE OF CALCULOUS PATIENTS, AFTER ABSORPTION OF THE MATRIX IMMUNE SERUM WITH HUMAN SERUM PROTEINS AND TNDS OF NORMAL URINE. Peripheral wells contain the same preparations as in Figure 8; center well contains the same immune serum after absorption.
C. The nondialyzable but ultrafiltrable solids (UF-O) of calculous urine. This fraction gave no immunological reaction with any preparation of matrix immune serum. These results indicate that a substance with immunological determinant groupings identical with the matrix substance A component of calculous matrix is present in the urine of patients who have recently formed calculi, but is absent or undetectable (concentrations less than $5 \mathrm{mg}$ per 24 hours) in normal urine. This substance is moderately soluble in veronal buffer, but is probably of relatively large molecu-

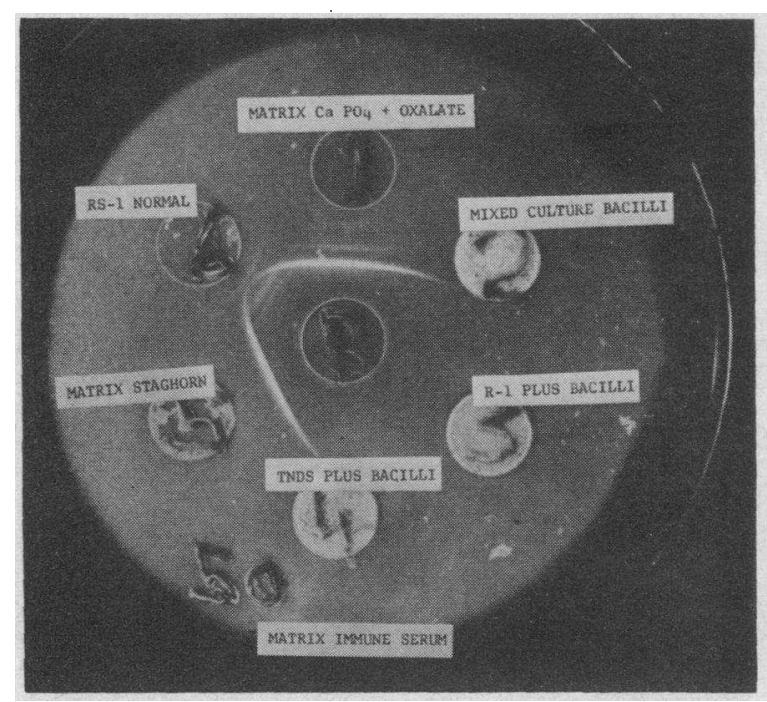

Fig. 10. Absence of PRecipitating antibodies to BACILLI IN RABBIT SERA IMMUNE TO STAGHORN CALCULOUS MATRIX. Well 2 contains a mixture of 6 species of bacilli recovered from the urine of patients with large renal calculi. Wells 3 and 4 contain a mixed culture of the same bacilli after 72 hours' incubation with nondialyzable solids from normal urine.

lar weight, since it does not pass ultrafilter membranes of $20 \mathrm{~m} \mu$ average pore diameter.

\section{Section $V$. Immunological studies of bacterial activity and stone matrix}

Urinary nondialyzable solids from 18 patients with classical, far advanced, bacterial pyelonephritis and no calculous disease were studied. Only one patient was found to have material in the urine which gave an immunological reaction of identity with calculous matrix substance $A$ as described in Section I. This patient had been a paraplegic for 16 years and had advanced osteoporosis with 
urinary calcium excretion rates consistently below $50 \mathrm{mg}$ per 24 hours. The reactive substance was found in the RS-1 fraction of the urine.

Broth cultures of nine species of bacteria commonly associated with stone formation were tested for the presence of substances with immunological reactivity to six preparations of matrix immune serum. No precipitin activity was found by either tube dilution or gel diffusion techniques (Figure 10).

When the R-1, RS-1, or TNDS from normal urine was added to the broth cultures and incubation repeated, no evidence of any immunological reactivity of these preparations to matrix immune sera could be demonstrated (Figures 11 and 12). Any precipitation observed in these preparations was demonstrated to result from the presence of antibodies to normal urinary solids in the antimatrix sera.

\section{DISCUSSION}

Anderson, Lepper and Winzler (8) have published data relative to immunological properties of renal calculous matrix. We find no contradictions in the data derived from their study of antisera protein specifically combined with insoluble matrix and the data derived from the Ouchterlony gel diffusion techniques reported here. The techniques employed by these investigators provide information relative to the sum of all antibodyantigen reactions occurring in their various test substances. It is apparent that immunological reactivity of normal urine to matrix immune serum is due to small amounts of urinary proteins present in matrix pooled from many calculi. The reactivity of calculous urine to such matrix immune serum represents the sum of normal urinary protein and matrix substance $A$ antigen-antibody systems. It is fortuitous that the matrix substance $A$, by virtue of its quantitative or antigenic superiority, or both, provides a very high titer of anti-A antibody when whole matrix is employed as the antigen.

Keutel, Hermann and Licht (12) studied oxalate stone matrix with respect to the presence of immunoelectrophoretically detectable serum components. They obtained evidence for the absence of seven and for the presence of nine others. It appears significant that one component of matrix appears to be quantitatively in excess of all others,

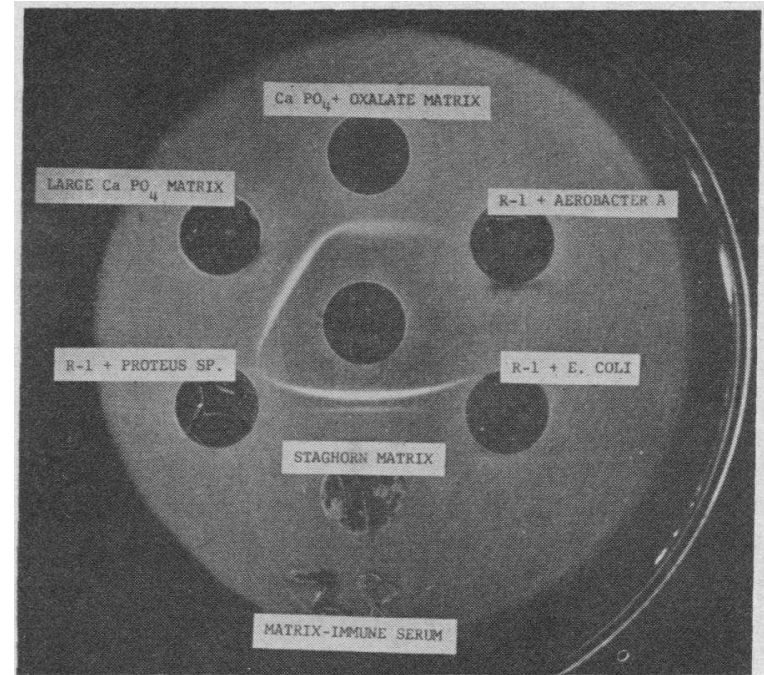

Fig. 11. AbSence of PRecipitating antibodies in maTRIX IMMUNE SERUM TO PURE CULTURES OF URINARY PATHOGENS CONTAINING R-1 SOLIDS OF NORMAL URINE.

and that this component is not detectable in serum. Until a more complete identification can be made, this antigenic substance has been designated "matrix substance A" on the basis of the following characteristics.

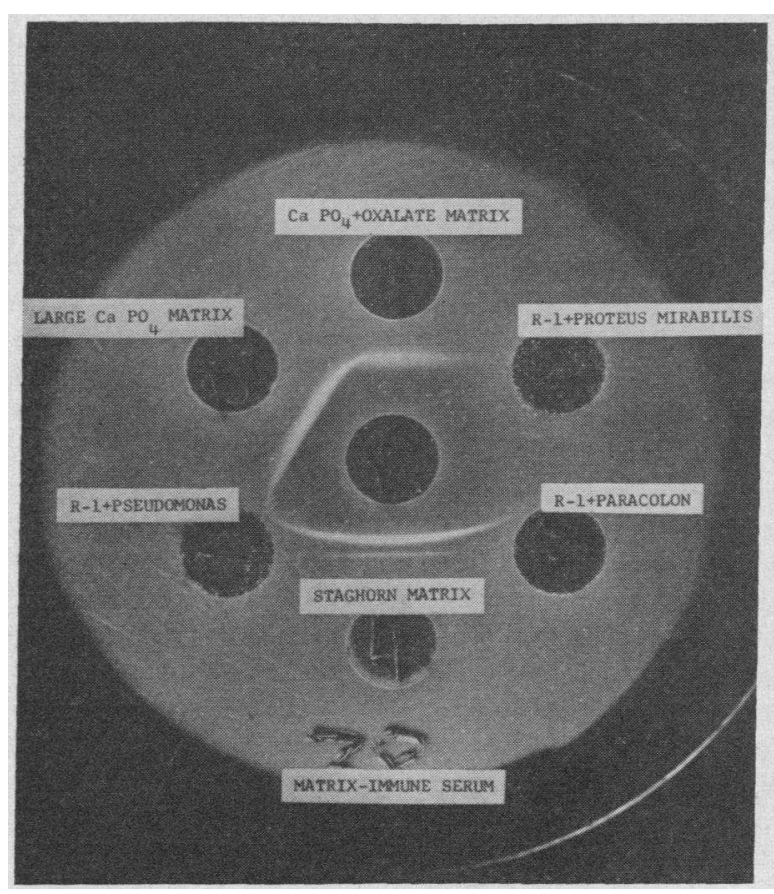

Fig. 12. AbSENCE OF PRECIPITATING ANTIBodies IN MATRIX IMMUNE SERUM TO PURE CULTURES OF URINARY PATHOGENS CONTAINING R-1 SOLIDS OF NORMAL URINE. 
1. It is present in all calcigerous calculi, giving an immunological reaction of identity with all other matrices from calcium-containing calculi.

2. It is present in the nonultrafiltrable, veronalsoluble fraction of urine from patients forming urinary calculi. Considerable variation in the concentration of substance A in the RS-1 solids of urine of calculous patients has been noted. By the techniques employed, it was demonstrable in only 68 per cent of unselected calculous patients on test of a single 24-hour specimen of urine. Repeated testing of urine will increase the number of positive urines to approach 100 per cent in patients who recently formed calculi. In patients who had formed only one calculus per year, this matrix substance was demonstrable in only 8 per cent of single urine specimens.

3. Quantitatively it is probably the largest component of matrix. When whole matrix is the antigen, the antibody titer to this component is consistently greater than that of other antigens in matrix. Progressive dilutions either of matrix or of antiserum will result in complete loss of Ouchterlony precipitin zones of all other antigens before the matrix component A system is appreciably affected.

4. The matrix immune serum, after absorption with human serum and TNDS of normal urine, has no immunological reactivity with blood serum or nondialyzable urinary solids of normal persons, but retains its immunological reactivity for matrix substance $A$ both in calculi and in urine from calculous patients.

5. Pathogenic bacteria recovered from urine of calculous disease patients make no contribution to the precipitin-forming antigenic components of stone matrix, either from their metabolites, bacterial cell bodies, or enzymatic action on nondialyzable solids of normal urine.

Present data indicate that matrix substance A occurs only in calculi and inconstantly in the freshly voided urine of stone-forming patients. The presence of this material in the urine indicates that it is not an artifact produced in the calculus either during its retention in the urinary tract or in the process of recovery of the matrix. Absence of this material from body fluids other than urine suggests the urinary system as the origin. Studies now being reported indicate that the urinary system below the collecting tubules is not the source of this material (13). The renal parenchyma is thus considered to be the most probable source. Anderson and colleagues' observation of a positive correlation between 24-hour volume and matrix immune serum reactivity of calculous urine may be due to the renal excretion or exudation of this material. If bacteria are involved in its production, their action must be a localized effect upon renal parenchymal cells.

The insolubility of matrix substance $A$ recovered from calculi as compared with the relatively high solubility of this substance in calculous urine may be due to "denaturation" of a proteinaceous material.

\section{SUM MARY}

Calcigerous stone matrix contains at least two and commonly three or more immunologically discrete components.

Some of these components have immunological counterparts in normal human blood serum and in the total nondialyzable solids of normal urine.

One component of stone matrix is immunologically more prominent than any of the others. It gives a "reaction of identity" with matrix from all calcigerous calculi. It has been identified only in the matrix of urinary calculi and in the relatively soluble nonultrafiltrable (RS-1) solids of urine from patients with renal calculi. This component of stone matrix is designated "matrix substance A" pending its isolation and further characterization.

Matrix substance $\mathrm{A}$ has not been immunologically identifiable in normal or pyelonephritic urine, in serum or erythrocytes of normal subjects or patients with stones, in blood or matrix from human bone, or in human saliva. Bacteria recovered from patients with calculi have not produced a substance immunologically reactive to matrix immune sera either in pure culture or in cultures containing total nondialyzable solids of normal urine.

\section{ACKNOWLEDGMENT}

The authors wish to acknowledge the technical assistance of Betty Jean Masten, MT, A.S.C.P., and Robert Jackson.

\section{REFERENCES}

1. Boyce, W. H., Pool, C. S., Meschan, I., and King, J. S., Jr. Organic matrix of urinary calculi. Microradiographic comparison of crystalline structure 
with microscopic and histochemical studies. Acta radiol. (Stockh.) 1958, 50, 543.

2. Boyce, W. H., and King, J. S., Jr. Crystal-matrix interrelations in calculi. J. Urol. (Baltimore) 1959, 81, 351.

3. King, J. S., Jr., and Boyce, W. H. Amino acid and carbohydrate composition of the mucoprotein matrix in various calculi. Proc. Soc. exp. Biol. (N.Y.) 1957, 95, 183.

4. King, J. S., Jr., and Boyce, W. H. Analysis of renal calculous matrix compared with some other matrix materials and with uromucoid. Arch. Biochem. 1959, 82, 455.

5. Dulce, J. H. Uber die Harnkolloide in Formalgenese der Harnsteine, K. Boshamer, Ed. Basle, S. Karger, 1958, p. 65.

6. Thiele, H. Synthese mizellarer Strukturen und intermizellare Kristallisation in Formalgenese der Harnsteine, K. Boshamer, Ed. Basle, S. Karger, 1958, p. 74.

7. Gasser, G., Brauner, K., and Preisinger, A. Die Konkrementbildungen der Blase und das Harnsteinproblem. II. Z. Urol. 1957, 50, 445.

8. Anderson, A. J., Lepper, M. H., and Winzler, R. J. Studies on urine colloids. II. Production of an antibody to the insoluble organic matrix of renal calculi and determination of a soluble antigen in the urine of patients with poliomyelitis. Amer. J. med. Sci. 1960, 240, 311.

9. Boyce, W. H., King, J. S., Jr., Little, J. M., and Artom, C. Total nondialyzable solids (TNDS) in human urine. II. A method for reproducible fractionation. J. clin. Invest. 1958, 37, 1658.

10. Boyce, W. H., King, J. S., Jr., and Fielden, M. L. Total nondialyzable solids (TNDS) in human urine. IX. Immunochemical studies of the R-1 "uromucoid" fraction. J. clin. Invest. 1961, 40, 1453.

11. Hodgkinson, A., Purton, M. J., and Pyrah, L. N. Some observations on the mode of formation of oxalate-containing urinary calculi. Lancet 1961, ii, 451.

12. Keutel, H. J., Hermann, G., and Licht, W. Immunoelektrophoretische Untersuchungen über den serumidentischen Anteil der Harnkolloide und ihre Bedeutung bei der Harnsteinbildung. Clin. chim. Acta 1959, 4, 665.

13. Edwards, C. N. Studies of urothelium III. Experimental stone formation in the dog. To be published. 